\title{
New records of 43 spider species from the Mountain Zebra National Park, South Africa (Arachnida: Araneae)
}

\section{A.S. DipPenaAR-SChOEMan}

\begin{abstract}
Dippenaar-Schoeman, A.S. 2006. New records of 43 spider species from the Mountain Zebra National Park, South Africa (Arachnida: Araneae). Koedoe 49(2): 23-28. Pretoria. ISSN 0075-6458.
\end{abstract}

\begin{abstract}
Forty-three new spider species records have been added to the check list of spiders published in 1988 on the spiders of the Mountain Zebra National Park. An updated check list with information on the guilds, habitat preferences and web types are provided for the 34 families, 66 genera and 76 species presently known from the park. A total of $3.8 \%$ of the spiders known from South Africa are presently protected in the park. Fourteen of the 34 families representing 35 species $(46.1 \%)$ are web builders and twenty-one families represented by 41 species $(53.9 \%)$ are wanderers. The Thomisidae are the most diverse family represented by 11 species. This is an inventory project of the South African National Survey of Arachnida (SANSA) for spiders in the Nama Karoo and conserved areas.
\end{abstract}

Key words: Araneae, check list, Mountain Zebra National Park, Nama Karoo, spiders, South African National Survey of Arachnida.

A.S. Dippenaar-Schoeman, Agricultural Research Council, Plant Protection Research Institute, Biosystematics Division, Private Bag X134, Queenswood, 0121 Republic of South Africa/ Department of Zoology and Entomology, University of Pretoria, Pretoria, 0002 Republic of South Africa.

\section{Introduction}

This study forms part of the South African National Survey of Arachnida (SANSA), initiated in 1997 with the main aim to create an inventory of the arachnid fauna of South Africa (Dippenaar-Schoeman \& Craemer 2000). One of the objectives of SANSA is to assess the number of arachnid species presently protected in conserved areas in the country. Check lists of spiders are now available for three national parks, three nature reserves and a conservancy. These areas include: Mountain Zebra National Park (Dippenaar-Schoeman 1988); Karoo National Park (Dippenaar-Schoeman et al. 1999); Kruger National Park (DippenaarSchoeman \& Leroy 2002); Roodeplaatdam Nature Reserve (Dippenaar-Schoeman et al. 1989); Makelali Nature Reserve (Whitmore et al. 2001, 2002); Swartberg Nature Reserve (Dippenaar-Schoeman et al. 2005); and the Soutpansberg Conservancy (Foord et al. 2002).

The Mountain Zebra National Park (MZNP) is $24 \mathrm{~km}$ west of Cradock in the Eastern Cape Province and was proclaimed as a protected area in 1937. It is situated in a zone transitional between the Nama Karoo Biome in the west and the Grassland Biome in the East but is classified as Nama Karoo (Rutherford \& Westfall 1986). Another objective of SANSA is to determine the diversity of the arachnids from the different floral biomes. Little is known about the spider fauna of the Nama Karoo. Only three published surveys appeared, i.e., on the MZNP (DippenaarSchoeman 1988) that listed 32 species from 16 families; the Karoo National Park (Dippenaar-Schoeman et al. 1999) with 116 species from 38 families; and the Nama Karoo grassland in the Northern Cape Province (Haddad \& Dippenaar-Schoeman 2005) where 20 
Table 1

Guild classification of spiders collected in the Mountain Zebra National Park

\begin{tabular}{|c|c|c|}
\hline Guilds & Abbreviation & Guild explanation \\
\hline \multicolumn{3}{|c|}{ Wandering Spiders } \\
\hline \multicolumn{3}{|c|}{ Ground wandering spiders (GW) } \\
\hline $\begin{array}{l}\text { Free living } \\
\text { Burrow living } \\
\text { Rock living } \\
\text { Sand living }\end{array}$ & $\begin{array}{l}\text { FGW } \\
\text { BGW } \\
\text { RGW } \\
\text { SGW }\end{array}$ & $\begin{array}{l}\text { free-living spiders running on the soil surface when active } \\
\text { living in burrows } \\
\text { living permanently or semi-permanently on or under rocks } \\
\text { living beneath the soil surface when not active }\end{array}$ \\
\hline \multicolumn{3}{|c|}{ Plant wandering spiders (PW) } \\
\hline $\begin{array}{l}\text { Grass living } \\
\text { Flower living } \\
\text { Foliage living }\end{array}$ & $\begin{array}{l}\text { GPW } \\
\text { FPW } \\
\text { FOPW }\end{array}$ & $\begin{array}{l}\text { found mainly on grass } \\
\text { found mainly on flowers } \\
\text { found mainly on the foliage of shrubs, herb or thicket }\end{array}$ \\
\hline \multicolumn{3}{|l|}{ Web-builders } \\
\hline Orb-web & OWB & $\begin{array}{l}\text { webs consist of a frame with mooring and bridge lines that } \\
\text { anchor the web and radial signal threads arranged like the ribs of } \\
\text { an umbrella, converging onto the centre of the web with circular } \\
\text { spiral threads }\end{array}$ \\
\hline Funnel-web & FWB & webs made over soil surface with a funnel-shaped retreat \\
\hline Gumfoot-web & GWB & $\begin{array}{l}\text { three-dimensional webs consisting of a central area with or with- } \\
\text { out a retreat. The upper part comprises mooring, signal and catch } \\
\text { threads and a lower part with mooring and catch threads. The } \\
\text { lower catch threads studded with sticky droplets are attached to } \\
\text { the substrate }\end{array}$ \\
\hline Retreat-web & RWB & $\begin{array}{l}\text { silk threads radiating from retreat used to catch prey; usually } \\
\text { made with cribellate silk }\end{array}$ \\
\hline Sheet-web & SHWB & $\begin{array}{l}\text { webs that usually consist of an upper sheet with mooring, signal } \\
\text { and catch threads. }\end{array}$ \\
\hline Space-web & SPWB & $\begin{array}{l}\text { webs that fill open space and are usually attached with mooring } \\
\text { threads to different substrates. }\end{array}$ \\
\hline
\end{tabular}

families and 56 species of ground-dwelling spiders were collected.

Since the publication of the previous check list of spider species from the MZNP (Dippenaar-Schoeman 1988) some additional collecting has been undertaken.

In this paper an updated annotated check list is provided with information on the guilds, habitat preferences and web types.

\section{Materials and methods}

The check list provides an updated list of species names, including recent taxonomic name changes for some species. Due to new taxonomic information several species that were previously only identified to generic level are now identified to species level. Additional information is also provided on species' behaviour, based on the different guilds they occupy. The two main guild categories are free-living wandering spiders and web builders (Table 1). Voucher specimens are housed in the National Collection of Arachnida, ARC-Plant Protection Research Institute, Pretoria.

\section{Results}

Forty-three new records of spiders are listed, as well as species names of previous records that could only be identified to generic level (Table 2). The number of spider families recorded from the MZNP has increased from 
Table 2

Check List of the spider fauna of the Mountain Zebra National Park ( $n r=$ new record)

Class Arachnida

Family / genera /species

Guilds

Record

1. Family Agelenidae (funnel-web spiders)

Benoitia ocellata (Pocock, 1900)

FWB

$\mathrm{nr}$

2. Family Ammoxenidae (termite feeders)

Ammoxenus pentheri Simon, 1896

SGW

nr

3. Family Araneidae (orb-web spiders)

Araneus sp. (immature)

OWB

OWB

Argiope australis (Walckenaer, 1805)

Caerostris sexcuspidata (Fabricius, 1793)

OWB

Cyclosa insulana (Costa, 1834)

OWB

Cyrtophora citricola (Forskål, 1775)

Larinia bifida Tullgren, 1910

OWB

OWB

Nemoscolus tubicola (Simon, 1887)

Neoscona quincasea Roberts 1983

OWB

Neoscona subfusca (C.L. Koch, 1837)

Neoscona triangula (Keyserling, 1864)

OWB

OWB

OWB

Dippenaar-Schoeman 1988

Bjørn 1997 (new name)

id to species level

id to species level

$\mathrm{nr}$

id to species level

nr

Dippenaar-Schoeman 1988

nr

nr

4. Family Caponiidae (orange lungless spiders)

Caponia sp. (immature)

FGW

$\mathrm{nr}$

5. Family Clubionidae (sac spiders)

Clubiona sigillata Lawrence, 1952

FOPW

Dippenaar-Schoeman 1988

6. Family Cyrtaucheniidae (wafer-lid trapdoor spiders)

Ancylotrypa sororum (Hewitt, 1916)

BGW

$\mathrm{nr}$

7. Family Dictynidae (meshweb spiders)

Mashimo leleupi Lehtinen, 1967

RWB

Dippenaar-Schoeman 1988

8. Family Eresidae (velvet spiders)

Gandanameno spenceri (Pocock, 1900)

Stegodyphus tentoriicola Purcell, 1904

RWB

RWB

$\mathrm{nr}$

nr

9. Family Gnaphosidae (ground spiders)

Asemesthes albovittatus Purcell, 1908

Micaria sp. (mmature)

FGW

FGW

nr

$\mathrm{nr}$

10. Family Hahniidae (comb-tailed spiders)

Hahnia tabulicola Simon, 1898

SHWB nr

11. Family Idiopidae (spurred trapdoor spiders)

Heligmomerus deserti Pocock, 1901

BGW nr

12. Family Linyphiidae (hammocksheet-web spiders)

Ceratinopsis sp. (immature)

SHWB

Metaleptyphantes familiaris Jocqué, 1984

SHWB

Microlinyphia sterilis (Pavesi, 1883)

SHWB

$\mathrm{nr}$

$\mathrm{nr}$

Dippenaar-Schoeman 1988

13. Family Lycosidae (wolf spiders)

Pardosa crassipalpis Purcell, 1903

Proevippa dregei (Purcell, 1903)

FGW

FGW

id to species level

nr

14. Family Miturgidae

Cheiracanthium furculatum Karsch, 1879

FOPW

id to species level

15. Family Nemesiidae (wishbone trapdoor spiders)

Hermacha crudeni Hewitt, 1913

BGW

id to species level 
16. Family Nephilidae (golden orb-web spiders)

Nephila senegalensis (Walckenaer, 1842)

OWB

Dippenaar-Schoeman 1988

Nephila fenestrata Thorell, 1859

OWB Dippenaar-Schoeman 1988

17. Family Oxyopidae (lynx spiders)

Hamataliwa sp. (immature)

GPW nr

Oxyopes bothai Lessert, 1915

GPW

id to species level

Peucetia nicolae Van Niekerk \& Dippenaar-

GPW

Schoeman, 1994

Peucetia maculifera Pocock, 1900

GPW

Van Niekerk \& DippenaarSchoeman 1994

Van Niekerk \& Dippenaar-

Schoeman 1994

18. Family Palpimanidae (palp-footed spiders)

Palpimanus capensis Simon, 1893

FGW $\quad$ nr

19. Family Philodromidae (small huntsman spiders)

Hirriusa arenacea (Lawrence, 1927)

Philodromus sp.

Thanatus sp.

FGW

FPW

FPW

$\mathrm{nr}$ Dippenaar-Schoeman 1988

20. Family Pholcidae (daddy-long-legs spiders)

Smeringopus natalensis Lawrence, 1947

Smeringopus similis Kraus, 1957

SPWB

SPWB

nr

nr

21. Family Phyxelididae (retreat-web spiders)

Vidole capensis (Pocock, 1900)

RWB

$\mathrm{nr}$

22. Family Pisauridae (nursery-web spiders)

Afropisaura sp.

Euprosthenops pulchellus Pocock, 1902

Voraptus sp. (immature)

GPW

FWB

FWB

$\mathrm{nr}$

$\mathrm{nr}$

Dippenaar-Schoeman 1988

23. Family Salticidae (jumping spiders)

Dendryphantes sp.

Myrmarachne solitaria Peckham \& Peckham, 1903

GPW

GPW

Natta chionogaster (Simon, 1901)

FGW

Salticidae indet.

GPW

id to species level

id to species level

id to species level

Dippenaar-Schoeman 1988

24. Family Scytodidae (spitting spiders)

Scytodes cedri Purcell, 1904

FGW

Dippenaar-Schoeman 1988

25. Family Segestriidae (tube-web spiders)

Ariadna hottentotta Purcell, 1908

RWB nr

26. Family Selenopidae (wall spiders)

Anyphops capensis (Lawrence, 1940)

FGW nr

27. Family Sparassidae (huntsman spider)

Olios sp. (immature)

FPW/FGW nr

28. Family Tetragnathidae (water orb-web spiders)

Leucauge decorata (Blackwall, 1864)

Pachygnatha leleupi Lawrence, 1952

OWB

OWB

Tetragnatha sp. (immature)

OWB

$\mathrm{nr}$

nr

Dippenaar-Schoeman 1988

29. Family Theridiidae (gumfoot-web spiders)

Achaearaneae tepidariorum (C.L. Koch, 1841)

Enoplognatha molesta O.P.-Cambridge, 1904

GFWB

GFWB

Latrodectus cinctus Blackwall, 1865

GFWB

Latrodectus geometricus C.L. Koch, 1841

GFWB

nr

id to species level

nr

Lotz 1994 
30. Family Thomisidae (crab spiders)

Diaea puncta Karsch, 1884

Holopelus albibarbis Simon, 1895

Misumenops rubrodecoratus Millot, 1941

Runcinia aethiops (Simon, 1901)

Runcinia flavida (Simon, 1881)

Runcinia grammica (L. Koch, 1837)

Synema imitator (Pavesi, 1883)

Synema vallotoni Lessert, 1923

Thomisus blandus Karsch, 1880

Thomisus stenningi Pocock, 1900

Xysticus sp.

31. Family Theraphosidae (baboon spiders)

Harpactirella sp.

32. Family Trochanteriidae (scorpion spider)

Platyoides leppanae Pocock, 1902

33. Family Uloboridae (hackled orb-web weavers)

Miagrammopes constrictus Purcell, 1904

Uloborus planipedius Simon, 1896

34. Family Zodariidae (ant eaters)

Diores spinulosus Jocqué, 1990

$\begin{array}{ll}\text { GPW } & \text { nr } \\ \text { FPW } & \text { Dippenaar-Schoeman 1988 } \\ \text { FPW } & \text { Dippenaar-Schoeman 1988 } \\ \text { GPW } & \text { Dippenaar-Schoeman 1988 } \\ \text { GPW } & \text { Dippenaar-Schoeman 1988 } \\ \text { GPW } & \text { nr } \\ \text { FPW/OPW } & \text { nr } \\ \text { FPW } & \text { nr } \\ \text { FPW } & \text { nr } \\ \text { FPW } & \text { Dippenaar-Schoeman 1988 } \\ \text { FGW } & \text { nr } \\ & \\ \text { BGW } & \text { nr } \\ & \\ \text { FGW } & \text { nr } \\ & \\ \text { OWB } & \text { nr } \\ \text { OWB } & \text { id to species level } \\ \text { FGW } & \end{array}$

16 to 34 , the genera from 29 to 66 and the species from 32 to 76 . Mountain Zebra National Park represents a new range extension for all 43 spider species. Fourteen of the 34 families representing 35 species $(46.1 \%)$ are web builders. They construct orb-webs (17 spp.); retreat-webs (5 spp.); sheet-webs and gumfoot-webs (4 spp. each); funnel-webs (3 spp.) and space-webs ( 2 spp.). Most of the web dwellers construct webs close to the soil surface and, except for some of the orb-web spiders, most are nocturnal and not easily seen. The few diurnal species include the two large golden orb-web spiders Nephila senegalensis (Walckenaer) and N. fenestrata Thorell, the garden orb-web spiders Argiope australis (Walckenaer) and the tropical tentweb spiders Cyrtophora citricola (Forskål).

Twenty-one families represented by 41 species $(53.9 \%)$ are wanderers. Of these, 23 species are free-living plant dwellers, 14 are free-living ground dwellers and four species are burrow dwellers. Of the burrow dwellers three species are trapdoor spiders: Ancylo- trypa sororum (Hewitt) (Cyrtaucheniidae), Heligmomerus deserti Pocock (Idiopidae) and Hermacha crudeni Hewitt (Nemesiidae). The fourth burrow dweller is a lesser baboon spider (Harpactirella sp.) of the family Theraphosidae.

\section{Discussion and conclusion}

With the ecology and diversity of the spider fauna of South Africa so poorly known, each study is a contribution to our knowledge on the geographical distribution of spider species. It forms part of the South African National Survey of Arachnida (SANSA) for the Nama Karoo Biome and as such, represents new distribution records for 43 species.

\section{Acknowledgements}

I wish to thank Marie de Jager for specimens collected and the warden and officials of the Mountain Zebra National Park for their assistance. Thanks are due to Ms. A.M van den Berg of ARC-Plant 
Protection Research Institute for comments on the manuscript.

\section{References}

BJøRN, P. P. 1997. A taxonomic revision of the African part of the orb-weaving genus Argiope (Araneae: Araneidae). Entomologica Scandinavica 28: 199-239.

DipPEnAAR-Schoeman, A.S. 1988. Annotated check list of the spiders (Araneae) of the Mountain Zebra National Park. Koedoe 31: 151-160.

DippenaAr-Schoeman, A.S. \& C. Craemer. 2000. The South African National Survey of Arachnida. Plant Protection News 56: 11-12.

DippenaAr-Schoeman, A.S. \& A. Leroy. 2003. A check list of the spiders of the Kruger National Park, South Africa (Arachnida: Araneae). Koedoe 46(1): 91-100.

DippenaAr-Schoeman, A.S., A. Leroy, M. DE Jager \& A. VAN DEN BERG. 1999. Spider diversity of the Karoo National Park, South Africa (Arachnida: Araneae). Koedoe 42(1): 31-42.

DippenaAR-Schoeman, A.S., A.M. VAn DEN BerG \& A. VAN DEN BERG. 1989. Species composition and relative seasonal abundance of spiders from the field and tree layers of the Roodeplaat Dam Nature Reserve. Koedoe 32(1): 25-38.

DippenaAr-Schoeman, A.S., A.E. VAn Der Walt, E. LE RouX \& A. VAN DEN BERG. 2005. The spiders of the Swartberg Nature Reserve in South Africa (Arachnida: Araneae). Koedoe 48(1): 77-86.

Foord, S.H., A.S. DipPENAAR-SchOEMAN \& M. VAN DER MERWE. 2002. A check list of the spider fauna of the Western Soutpansberg, South Africa (Arachnida: Araneae). Koedoe 45(2): 35-43.

Haddad, C.R. \& A.S. DippenaAR-Schoeman. 2005. Epigeic spiders (Arachnida: Araneae) in Nama Karoo grassland in the Northern Cape Province. Navorsinge van die Nasionale Museum, Bloemfontein 21: 1-10.

LotZ, L.N. 1994. Revision of the genus Latrodectus (Araneae: Theridiidae) in Africa. Navorsinge van die Nasionale Museum, Bloemfontein 10: 1-60.

Rutherford, M.C. \& R.H. WestFall. 1986. Biomes of southern Africa, an objective categorization. Memoirs of the Botanical Survey of South Africa 54: $1-98$.

VAn Niekerk, P. \& A.S. DippenaAR-Schoeman. 1994. A revision of the Afrotropical species of Peucetia (Araneae: Oxyopidae). Entomology Memoir, Department of Agriculture, South Africa 89: $1-50$.

Whitmore, C., R. Slotow, T.E. Crouch \& A.S. DipPenAaR-Schoeman. 2001. Checklist of spiders (Araneae) from savanna ecosystem, Northern Province, South Africa: including a new family record. Durban Museum Novitates 26: 10-19.

Whitmore, C., R. Slotow, T.E. Crouch \& A.S. DippenaAR-Schoeman. 2002. Diversity of spiders (Araneae) in a savanna reserve, Northern Province, South Africa. Journal of Arachnology 30: 344-356. 